\title{
Regulation of Glutamine Synthetase Isoenzymes in Rhizobium leguminosarum biovar viceae
}

\author{
By MAURO ROSSI, ROBERTO DEFEZ, MAURIZIO CHIURAZZI, \\ ALESSANDRO LAMBERTI, AMODIO FUGGI† AND \\ MAURIZIO IACCARINO* \\ International Institute of Genetics and Biophysics, CNR, via Marconi 10, 80125 Naples, Italy
}

(Received 22 September 1988; revised 14 November 1988; accepted 29 November 1988)

\begin{abstract}
Ammonia assimilation in Rhizobium leguminosarum biovar viceae strain RCR1001 (hereafter called $R$. leguminosarum) appears to take place only through the glutamine synthetase/glutamate synthase pathway since $(a)$ no glutamate dehydrogenase was detected in crude extracts of bacteria grown in different nitrogen sources, and $(b)$ the growth rate on glutamine as a nitrogen source was faster than that observed on $\mathrm{NH}_{4} \mathrm{Cl}$. In contrast to reports for other Rhizobium species, $R$. leguminosarum can definitely utilize $\mathrm{NH}_{4} \mathrm{Cl}$ for growth. $R$. leguminosarum contains two glutamine synthetase isoenzymes, GSI and GSII, which can be detected in the presence of each other by differential heat stability, or separated by affinity chromatography or immunoabsorption with an antiserum raised against pure GSI. GSII does not cross-react with an anti-GSI antiserum. GSI was shown to be reversibly adenylylated and it was also shown that adenylylation inhibits the biosynthetic activity of this enzyme, in a similar way to that reported for Escherichia coli glutamine synthetase and in contrast to that observed for glutamine synthetase of Rhizobium sp. strain ANU289. The apparent adenylylation level in different growth conditions changes from $21 \%$ to $99 \%$, indicating a physiological role of this posttranslational modification in the in vivo regulation of GSI activity. The intracellular concentration of GSI varies very little when $R$. leguminosarum is grown on different nitrogen sources (twofold when measured by the transferase assay, or fourfold when measured by ELISA). In addition, the concentration of mRNA specific for GSI in different nitrogen sources does not show appreciable differences. The intracellular concentration of GSII varies from a specific activity value higher than 1000 when $R$. leguminosarum is grown on glutamate or nitrate, to an undetectable level when grown on $\mathrm{NH}_{4} \mathrm{Cl}$. When $\mathrm{NH}_{4} \mathrm{Cl}$ is added to a culture growing in glutamate, GSII activity is rapidly diluted out, suggesting a post-translational mechanism of enzyme inhibition or inactivation. Chloramphenicol prevents the disappearance of GSII activity, thus suggesting that protein synthesis is required for this process.
\end{abstract}

\section{INTRODUCTION}

Two pathways of ammonia assimilation exist in bacteria: via glutamate dehydrogenase (GDH; EC 1.4.1.3) (reaction 1), and via glutamine synthetase (GS; EC 6.3.1.2) and glutamate synthase (GOGAT; EC 1.4.1.13) (reactions 2 and 3 respectively). The end product of both pathways is glutamate, from which nitrogen compounds of the cell are synthesized.

$$
\begin{gathered}
\mathrm{NH}_{4}^{+}+\text {2-oxoglutarate }+\mathrm{NAD}(\mathrm{P}) \mathrm{H} \stackrel{\mathrm{GDH}}{\longrightarrow} \text { glutamate }+\mathrm{NAD}(\mathrm{P})^{+} \\
\mathrm{NH}_{4}^{+}+\text {glutamate }+\mathrm{ATP} \stackrel{\mathrm{GS}}{\longrightarrow} \text { glutamine }+\mathrm{ADP}+\mathrm{P}_{\mathrm{i}} \\
\text { Glutamine }+ \text { 2-oxoglutarate + NADPH } \stackrel{\text { GOGAT }}{\longrightarrow} 2 \text { glutamate }+\mathrm{NADP}^{+}
\end{gathered}
$$

† Permanent address: Dipartimento di Biologia Vegetale, University of Naples, Italy.

Abbreviations: GDH, glutamate dehydrogenase; GOGAT, glutamate synthase; GS, glutamine synthetase; SVPD, snake venom phosphodiesterase. 
GDH has a high $K_{\mathrm{m}}$ for ammonia and thus only operates at high ammonia concentrations. GS/GOGAT is the major route of ammonia assimilation when ammonia is limiting. In enteric bacteria the use of these two pathways is genetically controlled in response to the availability of ammonia. These enzymes form part of a general nitrogen control system (see Gussin et al., 1986, for a review) which includes a number of enzymes involved in the breakdown of nitrogenous compounds. When ammonia is present at high concentrations, the genes for GS and other enzymes under nitrogen control are repressed, and GDH is induced. The converse occurs when ammonia is limiting, giving the cell the capability to use a variety of nitrogen sources. Additionally, GS activity is controlled biochemically in response to ammonia. In the presence of ammonia, adenyl groups are reversibly attached to GS, causing inactivation.

Two forms of glutamine synthetase, GSI and GSII, have been demonstrated in all species tested of the family Rhizobiaceae (Fuchs \& Keister, 1980). GSI has been shown to be similar to the single GS of enteric bacteria. It is an oligomeric enzyme consisting of 12 identical subunits of $M_{\mathrm{r}} 59000$, is relatively heat stable, and can be adenylylated (Darrow \& Knotts, 1977). In contrast, GSII is made of smaller subunits, of $M_{\mathrm{r}} 36000$, which are heat labile and not known to be modified after translation. GSI and GSII are products of different genes (Carlson et al., 1985; Colonna-Romano et al., 1987; Filser et al., 1986; Somerville \& Kahn, 1983).

We have previously reported (Colonna-Romano et al., 1987) the cloning and nucleotide sequence of the $R$. leguminosarum biovar viceae $g \ln A$ gene, the structural gene for GSI. Its deduced amino acid sequence shows $56 \%, 63 \%$ and $68 \%$ similarity with the deduced amino acid sequences of Anabaena, Escherichia coli and Azospirillum brasilense GSs respectively, and most of it is in boxes of identical amino acids. The deduced $M_{\mathrm{r}}$ of the protein is 52040 , in good agreement with that obtained from pure GSI. Upstream of the $g \ln A$ genes of $R$. leguminosarum and of Bradyrhizobium japonicum (Carlson et al., 1987) there is no regulatory sequence similar to that reported for $g \ln A$ of enteric bacteria (see, for example Dixon, 1984).

The gene of $B$. japonicum coding for GSII has been cloned and sequenced (Carlson \& Chelm, 1986). Comparison of the deduced amino acid sequence showed limited similarity to other bacterial GSs, but extensive similarity to a GS of Phaseolus vulgaris roots, thus suggesting that the gene coding for GSII might be of eukaryotic origin. Upstream of this gene there is a good consensus sequence for an $n t r$ promoter (Carlson et al., 1987).

The role of the enzymes for ammonia assimilation with respect to the symbiotic phenotype of Rhizobium spp. is not well understood. GDH is missing in several wild-type strains (Howitt \& Gresshoff, 1985; Bravo \& Mora, 1988) and not very active in others. Strains defective for GOGAT are $\mathrm{Nod}^{+}$and $\mathrm{Fix}^{+}$. Mutants of Rhizobium meliloti which lack GSI activity (Somerville $\& \mathrm{Kahn}, 1983$ ) are $\mathrm{Gln}^{+}$in the free-living form, probably because GSII expression substitutes for GSI; they are $\mathrm{Nod}^{+}$and Fix ${ }^{+}$. Mutants of $R$. leguminosarum biovar phaseoli lacking GSII are $\mathrm{Nod}^{+}$and $\mathrm{Fix}^{+}$(Morett et al., 1985). Mutants of $B$. japonicum lacking either GSI or GSII are $\mathrm{Gln}^{+}, \mathrm{Nod}^{+}$and $\mathrm{Fix}^{+}$; double mutants are Gln${ }^{-}$and $\mathrm{Nod}^{-}$(Carlson et al., 1987).

We started a study on the enzymes of ammonia assimilation in the free-living form of $R$. leguminosarum biovar viceae to understand nitrogen assimilation and its regulation. We have shown that GSI and GSII can be separated by affinity chromatography and that the former does not generate the latter, nor vice versa. We report evidence suggesting that adenylylation of GSI has physiological significance. Furthermore, we suggest that under certain conditions a posttranslational modification of GSII takes place.

\section{METHODS}

Bacterial strain. The strain used was R. leguminosarum biovar viceae LPR1105, a Rifr derivate of RCR1001 (Hooykaas et al., 1977).

Growth conditions. R. leguminosarum biovar viceae was grown on RMM (Hooykaas et al., 1977); the nitrogen sources used were glutamine, glutamate, $\mathrm{NH}_{4} \mathrm{Cl}$, or $\mathrm{KNO}_{3}$, each at a concentration of $1 \mathrm{~g} \mathrm{l}^{-1}$. This medium has a $\mathrm{pH}$ of $6 \cdot 3$; when $\mathrm{NH}_{4} \mathrm{Cl}$ is used as a nitrogen source the $\mathrm{pH}$ decreases to 5 and the growth rate is slower. To prevent acidification we added $100 \mathrm{mM}-\mathrm{MOPS}, \mathrm{pH} 7 \cdot 2$.

Cultures were grown at $30^{\circ} \mathrm{C}$ on a rotary shaker at 200 r.p.m.

Preparation of cell extracts. Bacteria $(50 \mathrm{ml}$ volumes, unless otherwise stated) were harvested in the exponential phase by centrifugation at $4{ }^{\circ} \mathrm{C}$, washed with $0.9 \% \mathrm{NaCl}$ and frozen as a pellet at $-20^{\circ} \mathrm{C}$. The pellet was 
resuspended in $1 \mathrm{ml}$ of extraction buffer (Ferguson \& Sims, 1971), sonicated twice for $45 \mathrm{~s}$, with a 1 min interval at $0{ }^{\circ} \mathrm{C}$, and centrifuged at $27000 \mathrm{~g}$ at $4{ }^{\circ} \mathrm{C}$ for $20 \mathrm{~min}$ to remove cell debris.

Heat treatment. Samples of cell extracts were heated at $55^{\circ} \mathrm{C}$ for $30 \mathrm{~min}$, rapidly cooled in ice and centrifuged; the supernatant was used for GS assays.

Enzyme assays. For the $\gamma$-glutamyltransferase activity of GSII, we used the method described by Ferguson $\&$ Sims (1971) and measured activity in samples of cell extract before and after heat treatment to assay the heat-stable fraction relative to total activity. The $\gamma$-glutamyltransferase activity of GSI was assayed according to the protocol of Shapiro \& Stadtman (1970) at pH 7.43 (the isoactivity point of the adenylylated and non-adenylylated form of GSI; see below) on cell extracts subjected to heat treatment. For the detection of GSI activity on gels (Fig. 1) the concentration of the substrates was doubled. The degree of adenylylation of GSI is given by the ratio of transferase activity at $\mathrm{pH} 7.43$ in the presence and absence of $60 \mathrm{mM}-\mathrm{MgCl}_{2}$. The biosynthetic activity of GSI was determined by the method of Bender et al. (1977) except that cetyltrimethylammonium bromide was omitted. Units of activity are given as nmol $\gamma$-glutamyl-hydroxamate formed $\min ^{-1}$. Specific activity is expressed as units (mg protein) ${ }^{-1}$. Treatment of purified GSI with snake-venom phosphodiesterase (SVPD) was performed with $500 \mu \mathrm{g} \mathrm{m} \mathrm{m}^{-1} \mathrm{SVPD}$

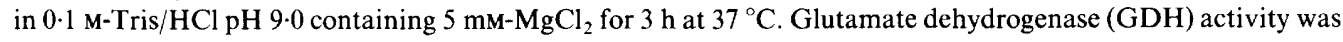
determined according to Prusiner et al. (1972).

Purification of GSI from $R$. leguminosarum biovar viceae. GSI was partially purified from $R$. leguminosarum biovar viceae grown in $\mathrm{RMM}$ plus $\mathrm{NH}_{4} \mathrm{Cl}$. A cell extract of an exponential-phase culture was adsorbed on a BlueSepharose column equilibrated in extraction buffer. After washing, GSI was eluted with 5 mM-AMP. Fractions containing activity were pooled, concentrated and dialysed. The specific activity increased 80 -fold.

Purification of R. leguminosarum biovar viceae GSI from Klebsiella pneumoniae and preparation of an antiserum. GSI was purified to homogeneity from $K$. pneumoniae strain UNF1827(p7D9) (Filser et al., 1986). This strain is $g \ln A$ and thus devoid of $K$. pneumoniae GS, while p7D9 codes for $R$. leguminosarum GSI. The following purification protocol was used. A crude extract in $10 \mathrm{~mm}-\mathrm{Tris} / \mathrm{HCl} \mathrm{pH} \mathrm{7.2,} 50 \mathrm{~mm}-\mathrm{K}_{2} \mathrm{SO}_{4}, 2.5 \mathrm{~mm}-\mathrm{MgSO}_{4}, 0.5 \mathrm{~mm}-\mathrm{EDTA}$, $0.5 \mathrm{~mm}$-mercaptoethanol was treated with $2 \%(\mathrm{w} / \mathrm{v})$ streptomycin sulphate; after centrifugation for $10 \mathrm{~min}$ at $12000 \mathrm{~g}$, the supernatant was adsorbed on a Blue-Sepharose column equilibrated in extraction buffer and eluted with a gradient of AMP. The enzyme appeared at about $2 \mathrm{mM}-\mathrm{AMP}$ and was $>95 \%$ pure when analysed by SDS polyacrylamide gel electrophoresis (PAGE).

This preparation was used to obtain a polyclonal antiserum from rabbit. After non-denaturing PAGE with pure GSI or with cell extracts of $R$. leguminosarum biovar viceae, an immunoblot was made according to Towbin $e t$ al. (1979) except that the nitrocellulose filter was washed extensively in cream-free milk containing 10 mM-phosphate buffer $\mathrm{pH} 7.4,0 \cdot 15 \mathrm{M}-\mathrm{NaCl}$ and $0.2 \%$ Tween 20 . After development, the filter showed a single band coincident with the band obtained when a twin portion of the gel was assayed for GS activity as described above (Fig. 1). On this gel, GSII activity is not detected, probably due to inactivation. Fig. 1 also shows that $K$. pneumoniae GS migrates faster than $R$. leguminosarum GSI on non-denaturing PAGE and that the anti-GSI antiserum does not react with $K$. pneumoniae GS, at least under the conditions used.

Immunoabsorption test. A $30 \mu \mathrm{l}$ volume of anti-GSI antiserum was mixed with $0.5 \mathrm{ml}$ Protein A-Sepharose $(0.1 \mathrm{~g}$ $\mathrm{ml}^{-1}$ ) in $20 \mathrm{~mm}$-imidazol/ $\mathrm{HCl} \mathrm{pH} 7 \cdot 0$ containing $1 \mathrm{mM}^{-\mathrm{MnCl}_{2}}$, kept at $4{ }^{\circ} \mathrm{C}$ overnight for absorption of the $\mathrm{IgG}$ fraction, packed into a column, washed and eluted with the same buffer. Cell extract $(150 \mu 1)$ was absorbed and $150 \mu \mathrm{l}$ fractions were collected and assayed for transferase activity.

ELISA assay. The competitive assay method described by Engvall (1980) was used. Microtitre plates were coated overnight at $4{ }^{\circ} \mathrm{C}$ with $100 \mu \mathrm{l}$ per well of pure GSI $\left(0.9 \mu \mathrm{g} \mathrm{ml} \mathrm{m}^{-1}\right.$ in $0.1 \mathrm{M}$-carbonate/bicarbonate coating buffer $\mathrm{pH} 9.6)$. After three washings with PBS (1.47 mM- $\left.\mathrm{KH}_{2} \mathrm{PO}_{4}, 8.1 \mathrm{~mm}-\mathrm{Na}_{2} \mathrm{HPO}_{4}, 137 \mathrm{~mm}-\mathrm{NaCl}, \mathrm{pH} 7.4\right)$ containing $0.05 \%$ Tween 20 , the wells were saturated with $0.5 \% \mathrm{BSA}$ in PBS $\left(100 \mu 1\right.$ per well for $1 \mathrm{~h}$ at $37^{\circ} \mathrm{C}$ in a humid chamber); after washing with PBS, $100 \mu \mathrm{l}$ samples containing polyclonal anti-GSI antiserum (1/800 dilution) and different dilutions of cellular extracts (or pure GSI for calibration) were added to the wells and incubated for $1 \mathrm{~h}$ at $37^{\circ} \mathrm{C}$, followed by washing and $1 \mathrm{~h}$ incubation with peroxidase-labelled goat anti-rabbit IgG at $1 / 200$ dilution; the amount of antibody bound was detected using $200 \mu \mathrm{l}$ of OPD $\left(0.33 \mathrm{mg} \mathrm{ml}^{-1} o\right.$-phenylenediamine hydrochloride and $0.016 \%$ hydrogen peroxide in $63 \mathrm{mM}-\mathrm{Na}_{2} \mathrm{HPO}_{4}, 29 \mathrm{~mm}$-citric acid, $\mathrm{pH} \mathrm{6.0)} \mathrm{for} 15 \mathrm{~min}$ at $37{ }^{\circ} \mathrm{C}$; the reaction was stopped by addition of $50 \mu \mathrm{l}$ of $2 \mathrm{M}-\mathrm{H}_{2} \mathrm{SO}_{4}$ and the absorbance at $420 \mathrm{~nm}$ was determined.

Extraction of RNA and slot-blot hybridization. Cells from a $250 \mathrm{ml}$ early-exponential-phase culture of $R$. leguminosarum biovar viceae LPR 1105 in RMM medium plus $100 \mu \mathrm{g}$ rifampicin $\mathrm{ml}^{-1}$ were spun down and resuspended in $2.5 \mathrm{ml}$ sterile $25 \%(\mathrm{w} / \mathrm{v})$ sucrose. This solution was transferred to a $50 \mathrm{ml}$ Falcon tube and $16.5 \mathrm{ml}$ M-STET $[4 \%(\mathrm{w} / \mathrm{v})$ sucrose, $6 \%(\mathrm{v} / \mathrm{v})$ Triton X-100, $60 \mathrm{~mm}$-Tris $/ \mathrm{HCl} \mathrm{pH} 8.0], 1.5 \mathrm{ml} \mathrm{lysozyme}\left(10 \mathrm{mg} \mathrm{ml}^{-1}\right.$, freshly prepared in sterile distilled water) and $0.15 \mathrm{ml}$ diethyl pyrocarbonate wre added. The mixture was incubated on ice for $5 \mathrm{~min}$. SDS ( $1 \mathrm{ml} ; 20 \%$, w/v) was added and boiled for $2 \mathrm{~min}$. After boiling, $0 \cdot 15 \mathrm{ml}$ diethyl pyrocarbonate was added and the viscous solution was cooled immediately in a bath of ethanol and dry ice. This solution was treated four times with phenol/chloroform/isoamyl alcohol $\left(50: 50: 1\right.$, by vol.) at $65^{\circ} \mathrm{C}$ and precipitated with $0 \cdot 7$ vol. of $2-$ propanol at room temperature. The pellet was redissolved in $40 \mathrm{ml} 2 \mathrm{M}-\mathrm{LiCl}$ and precipitated overnight at $4{ }^{\circ} \mathrm{C}$. 


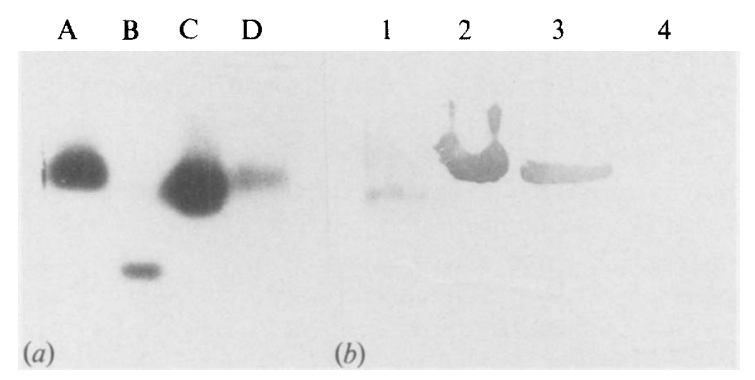

Fig. 1. Analysis of $R$. leguminosarum biovar viceae GSI by PAGE and immunoblotting. (a) Nondenaturing PAGE stained for transferase activity. Lanes: A, cell extract from $R$. leguminosarum grown in RMM plus glutamate; B, cell extract from $K$. pneumoniae, wild-type strain; C, R. leguminosarum GSI purified from $K$. pneumoniae strain UNF1827(p7D9); D, cell extract from $K$. pneumoniae strain UNF1827(p7D9). (b) Immunoblot, with an antiserum to $R$. leguminosarum GSI. Lanes: 1, cell extract from $K$. pneumoniae strain UNF1827(p7D9); 2, R. leguminosarum GSI purified from $K$. pneumoniae strain UNF1827(p7D9); 3, cell extract from $R$. leguminosarum grown in RMM plus glutamate; 4, cell extract from $K$. pneumoniae, wild-type strain.

After centrifugation RNA was redissolved in $40 \mathrm{~mm}-\mathrm{Tris} / \mathrm{HCl}, \mathrm{pH} 7 \cdot 9,10 \mathrm{~mm}-\mathrm{NaCl}, 6 \mathrm{~mm}-\mathrm{MgCl}_{2}$ and digested with pancreatic deoxyribonuclease. After precipitation, the RNA samples were resuspended in $\mathrm{H}_{2} \mathrm{O}$ containing $0.05 \%$ diethyl pyrocarbonate, boiled for $3 \mathrm{~min}$ and cooled on ice. Then $350 \mu \mathrm{l} 20 \times \mathrm{SSC}(1 \times \mathrm{SSC}$ is $0.15 \mathrm{M}-\mathrm{NaCl}$, $0.015 \mathrm{M}$-trisodium citrate, $\mathrm{pH} 7 \cdot 0$ ) was added to each $50 \mu \mathrm{l}$ RNA.

The samples were slot-blotted on nitrocellulose using a Schleicher \& Schuell Hybri-slot apparatus. The filters were hybridized with a riboprobe made of the EcoRI-SmaI fragment internal to the structural gene, cloned in the pGem 3 vector, prepared as described by Melton et al. (1984). Hybridization was carried out in: $50 \%(\mathrm{v} / \mathrm{v})$ formamide, $50 \mathrm{~mm}$-sodium pyrophosphate $\mathrm{pH} 6.5,0.8 \mathrm{M}-\mathrm{NaCl}, 1 \mathrm{~mm}-\mathrm{EDTA}, 5 \times$ Denhardt's solution $(1 \times$ Denhardt's solution is $0.02 \%$ BSA, $0.02 \%$ Ficoll, $0.02 \%$ polyvinylpyrrolidone) and denatured salmon sperm DNA $\left(100 \mu \mathrm{g} \mathrm{ml}^{-1}\right)$ at $55^{\circ} \mathrm{C}$. Filters were washed in $0 \cdot 1 \times \mathrm{SSC}, 0 \cdot 1 \% \operatorname{SDS}$ at $65^{\circ} \mathrm{C}$.

\section{RESULTS AND DISCUSSION}

\section{Glutamate dehydrogenase activity}

Cell extracts of $R$. leguminosarum biovar viceae grown in $\mathrm{NH}_{4} \mathrm{Cl}$, glutamate, glutamine or $\mathrm{KNO}_{3}$ as nitrogen sources had undetectable $\left[<3 \mathrm{nmol} \mathrm{min}^{-1}(\mathrm{mg} \text { protein })^{-1}\right]$ GDH activity when either NADH or NADPH was used as cofactor, whereas a wild-type strain of $E$. coli grown in $\mathrm{NH}_{4} \mathrm{Cl}$ gave an activity of 12 (with NADH) and 257 (with NADPH) units. This result suggests, as was found with other Rhizobium spp. (Howitt \& Gresshof, 1985; Ludwig, 1978; Darrow, 1980; Bravo \& Mora, 1988), that GDH activity is absent in $R$. leguminosarum biovar viceae under the conditions tested. In agreement with this hypothesis, $R$. leguminosarum biovar viceae grew slightly better on glutamine or glutamate than on $\mathrm{NH}_{4} \mathrm{Cl}$ (see Table 1), but E. coli grown in the same medium showed a marked preference for $\mathrm{NH}_{4} \mathrm{Cl}$ (the growth rate observed at $37^{\circ} \mathrm{C}$ in $\mathrm{RMM}$ was $138 \mathrm{~min}$ when glutamine was the nitrogen source, and $45 \mathrm{~min}$ with $\mathrm{NH}_{4} \mathrm{Cl}$ ).

\section{GSI and GSII activities}

After $5 \mathrm{~min}$ of preincubation at $55^{\circ} \mathrm{C}$ all the labile activity of a crude extract of $R$. leguminosarum biovar viceae disappeared, while a heat-stable fraction persisted, even after 90 min incubation. In agreement with previously published evidence (Darrow \& Knotts, 1977; Filser et al., 1986), we call GSI the heat-stable fraction and GSII the heat-labile one.

We separated GSI and GSII activities in the presence of each other by different methods.

(a) Affinity chromatography. A crude extract of $R$. leguminosarum biovar viceae grown in glutamate and containing both GSI and GSII was adsorbed on a Blue-Sepharose column previously equilibrated with extraction buffer containing $1 \mathrm{~mm}-\mathrm{MgCl}_{2}$. As shown in Fig. 2, part of the activity was not adsorbed and it was found to be heat labile; more activity was eluted with 5 mM-AMP and was found to be heat stable. Repeated adsorption-elution experiments of the 


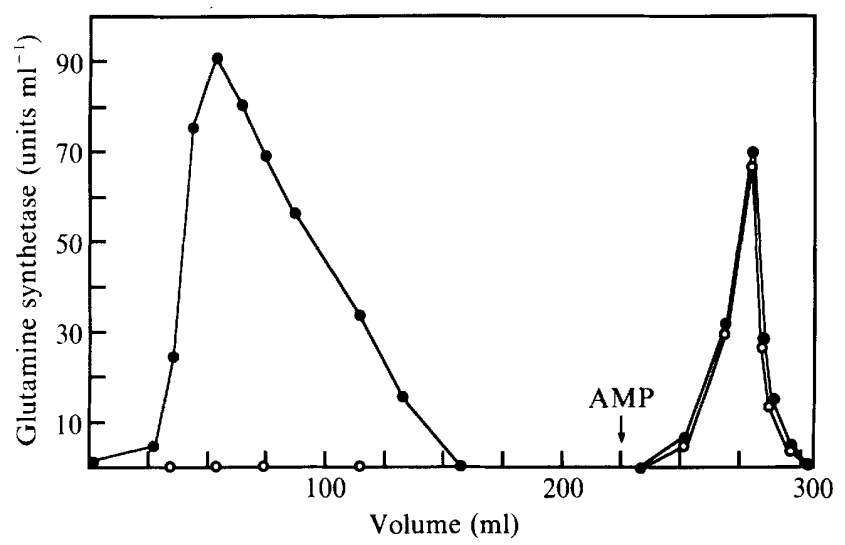

Fig. 2. Separation of GSI and GSII activities. A cell extract from $R$. leguminosarum biovar viceae grown in RMM plus glutamate was applied on a Blue-Sepharose column $(1.6 \times 10 \mathrm{~cm})$ previously equilibrated with extraction buffer containing $1 \mathrm{mM}-\mathrm{MgCl}_{2}$. After washing, the column was eluted with $5 \mathrm{mM}-\mathrm{AMP}$. Samples from each fraction were assayed for transferase activity before (O) and after $(O)$ heat treatment at $55^{\circ} \mathrm{C}$ for $30 \mathrm{~min}$.

Table 1. Influence of nitrogen sources on cell-doubling time and GSI and GSII transferase activities

\begin{tabular}{|c|c|c|c|c|c|}
\hline & & & GS & & \\
\hline $\begin{array}{l}\text { Growth } \\
\text { medium }\end{array}$ & $\begin{array}{l}\text { Doubling } \\
\text { time } \\
\text { (min) }\end{array}$ & $\begin{array}{l}\text { Specific } \\
\text { activity }\end{array}$ & $\begin{array}{c}\text { Degree of } \\
\text { adenylylation } \\
(\%)\end{array}$ & $\begin{array}{c}\text { Concentration } \\
\mu \mathrm{g}(\mathrm{mg} \text { protein })^{-1 *}\end{array}$ & $\begin{array}{c}\text { GSII } \\
\text { Specific } \\
\text { activity }\end{array}$ \\
\hline RMM + glutamate & 276 & 578 & 22 & $32 \cdot 5$ & 1023 \\
\hline $\mathrm{RMM}+\mathrm{KNO}_{3}$ & 300 & 394 & 51 & 18.93 & 1120 \\
\hline RMM + glutamine & 220 & 226 & 81 & $14 \cdot 93$ & 43 \\
\hline $\mathrm{RMM}+\mathrm{NH}_{4} \mathrm{Cl} \dagger$ & 318 & 228 & 86 & $8 \cdot 0$ & $<5$ \\
\hline
\end{tabular}

*These values were determined by ELISA and are the mean of at least three determinations. The standard error is less than $10 \%$.

†When $\mathrm{NH}_{4} \mathrm{Cl}$ was the nitrogen source 100 mM-MOPS was added (see Methods). In its absence the doubling time is higher than that reported here.

two fractions showed that either peak of activity did not generate the other. We conclude that GSI and GSII can be separated by Blue-Sepharose and behave as true isoenzymes.

(b) Immunoabsorption of GSI. A sample of a cell extract of $R$. leguminosarum biovar viceae grown in RMM with glutamate as the nitrogen source, containing 1316 units of heat-stable activity and 12639 units of heat-labile activity, was applied to a $0.5 \mathrm{ml}$ column of Protein-A Sepharose pretreated with anti-GSI antiserum. This column retained all ( $>98 \%$ ) heat-stable activity, and the heat-labile activity was recovered in the flow-through fractions. When ProteinA Sepharose was pretreated with non-immune serum the heat-stable activity was not absorbed. We conclude that the heat-stable fraction of GSI from crude cell extracts specifically crossreacts with the antiserum obtained against pure GSI and that under these conditions there is no cross-reactivity between GSI and GSII. Therefore, the activity detected in the immunoblot shown in Fig. 1(b), lane 3, is GSI.

\section{Adenylylation of GSI}

Since it has been reported that GSI activity of Rhizobium is subject to adenylylation (Darrow \& Knotts, 1977), we characterized GSI of $R$. leguminosarum biovar viceae from this point of view. A completely adenylylated GS from enteric bacteria is inactive in the transferase assay when $60 \mathrm{~mm}-\mathrm{MgCl}_{2}$ is added to the reaction mixture (Stadtman \& Ginsburg, 1974) and therefore the degree of adenylylation is measured as the ratio of transferase activity in the presence or 


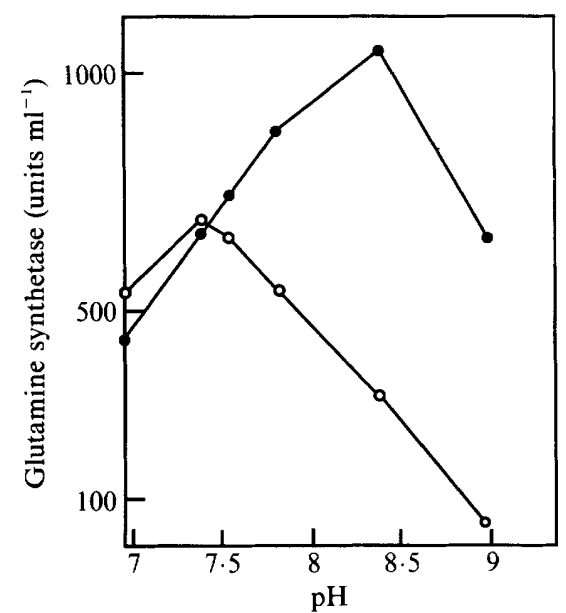

Fig. 3. Determination of the isoactivity point for GSI. A culture grown in RMM plus glutamate was divided in two aliquots and $\mathrm{NH}_{4} \mathrm{Cl}$ was added to one of them. After $20 \mathrm{~min}$, both cultures were collected and centrifuged. Cell extracts were prepared, heated at $55^{\circ} \mathrm{C}$ for $30 \mathrm{~min}$ and transferase activity determined at different $\mathrm{pH}$ values. Activity of cell extracts from $\mathrm{RMM}+$ glutamate; $\bigcirc$, activity of cell extracts from $\mathrm{RMM}$ plus glutamate, $\mathrm{NH}_{4} \mathrm{Cl}$ shocked.

absence of $60 \mathrm{~mm}-\mathrm{MgCl}_{2}$. However, a preliminary experiment should be performed with GSI to determine the activity as a function of $\mathrm{pH}$ for the adenylylated and non-adenylylated forms of the enzyme. As a source of relatively non-adenylylated GSI we used $R$. leguminosarum biovar viceae grown in RMM plus glutamate. As a source of adenylylated GSI we used the same culture incubated for $20 \mathrm{~min}$ with $1 \mathrm{mg} \mathrm{NH} \mathrm{NH} \mathrm{ml}_{4}^{-1}$. We prepared extracts from these two cultures and assayed GSI concentration by ELISA. Transferase activity values at different $\mathrm{pH}$ values are reported in Fig. 3. They are strikingly different and $\mathrm{pH} 7.43$ is the isoactivity point, namely the $\mathrm{pH}$ at which the same concentration of enzyme gives the same activity. When $60 \mathrm{mM}-\mathrm{MgCl}_{2}$ was added to the reaction mixture at $\mathrm{pH} 7 \cdot 43$, the activity of the extract from $R$. leguminosarum biovar viceae grown in glutamate decreased to $78 \%$ of the starting value, while the activity of the extract treated with $\mathrm{NH}_{4} \mathrm{Cl}$ decreased to $14 \%$. Assuming that adenylylation of GSI completely inhibits transferase activity in the protocol used, we conclude that GSI of these two cultures is $22 \%$ and $86 \%$ adenylylated respectively.

We showed that treatment with SVPD, which removes adenyl residues from $E$. coli GS, causes an increase in biosynthetic activity. We used a GSI preparation enriched 80 -fold from $R$. leguminosarum biovar viceae grown in $\mathrm{RMM}$ plus $\mathrm{NH}_{4} \mathrm{Cl}$. Treatment of GSI with SVPD for $3 \mathrm{~h}$ as described in Methods caused a decrease in adenylylation, from $87 \%$ to $20 \%$, and a doubling of biosynthetic activity, from 2290 to 4640 units (mg protein) ${ }^{-1}$. Therefore, contrary to what is observed with GSI from the slow-growing Rhizobium sp. strain ANU289 (Howitt \& Gresshoff, 1985), adenylylation of GSI inhibits biosynthetic activity and therefore has a physiological role analogous to that observed with $E$. coli GS. SVPD treatment caused a decrease $(23 \%)$ in transferase specific activity, from a value of 38500 to 29900 units (mg protein) ${ }^{-1}$; this may be due to a change in the kinetic constants of GSI related to the degree of adenylylation or to impurities in SVPD affecting the activity. We prefer the first hypothesis since, in a different protocol, when $\mathrm{NH}_{4} \mathrm{Cl}$ is added to a culture growing in glutamate, concomitant with an increase in the apparent degree of adenylylation of GSI from $21 \%$ to $100 \%$, there is a $50 \%$ increase in transferase specific activity, even if chloramphenicol $\left(300 \mu \mathrm{g} \mathrm{ml}^{-1}\right)$ is added to the culture $1 \mathrm{~h}$ before $\mathrm{NH}_{4} \mathrm{Cl}$ addition.

Transcriptional analysis of the glnA gene

The $R$. leguminosarum biovar viceae gene coding for GSI activity has been cloned and sequenced (Colonna-Romano et al., 1987). Regulatory sequences similar to those found 


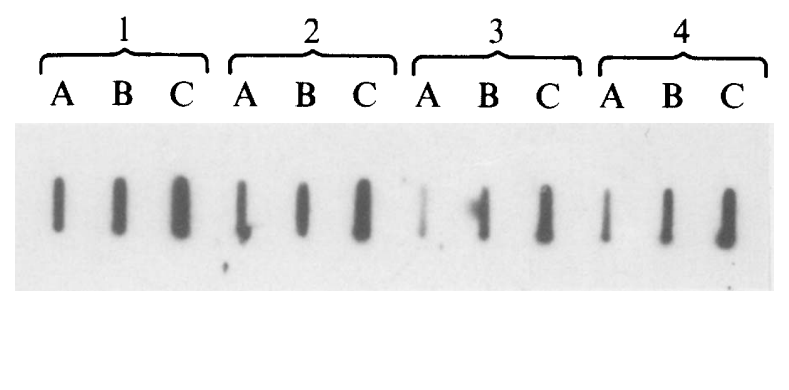

$\underset{100 \mathrm{bp}}{\longmapsto}$

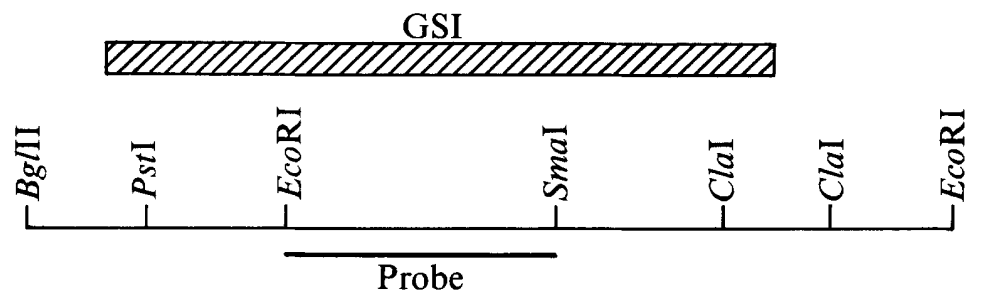

Fig. 4. Slot-blot hybridization experiment. Lanes A, B and C were loaded with: $1 \cdot 5$ (A), 3 (B) and $6 \mu \mathrm{g}$ (C) of RNA extracted from $R$. leguminosarum biovar viceae grown on $\mathrm{RMM}$ plus $\mathrm{NH}_{4} \mathrm{Cl}(1), \mathrm{KNO}_{3}(2)$, glutamine (3) or glutamate (4) as the sole nitrogen source. In the lower part of the figure a restriction map of the GSI region is shown. The hatched bar indicates the GSI coding region, while the black bar indicates the probe used in the slot-blot hybridization experiment.

upstream of $g \ln A$ in other enteric bacteria (Dixon, 1984) are not present upstream of the $R$. leguminosarum $g \ln A$ gene.

We quantified the GSI RNA transcript present in $R$. leguminosarum biovar viceae grown on different nitrogen sources by slot-blot hybridization, using a riboprobe of a fragment internal to $g \ln A$ (see Methods). By scanning analysis and using arbitrary units we found that the concentration of the GSI transcript present in $R$. leguminosarum biovar viceae with glutamine, glutamate, $\mathrm{KNO}_{3}$ or $\mathrm{NH}_{4} \mathrm{Cl}$ was $1 \cdot 0,1 \cdot 25,1 \cdot 8$ or $1 \cdot 85$, respectively. These results are shown in Fig. 4 and indicate that $g \ln A$ is regulated very little if at all at the transcriptional level. Similar results were reported for the B. japonicum $g \ln A$ gene (Carlson et al., 1987).

\section{Intracellular concentrations of GSI and GSII}

We measured the levels of GSI and GSII activities as well as the GSI concentration by ELISA in $R$. leguminosarum biovar viceae grown with different nitrogen sources. The intracellular concentration of GSI changes very little when the cells are grown in different nitrogen sources (Table 1). The apparent ratio of GSI present in bacteria grown with glutamate versus glutamine or $\mathrm{NH}_{4} \mathrm{Cl}$ is 2.5 as measured by the transferase assay, but is 4 when measured by ELISA. On the other hand, the degree of adenylylation changes from $22 \%$ with glutamate to $>80 \%$ with glutamine or $\mathrm{NH}_{4} \mathrm{Cl}$. Since under specific conditions (see below) the apparent degree of adenylylation approaches $100 \%$, it appears that regulation of GSI activity takes place mainly at the post-translational level.

In contrast, GSII activity, as measured by the transferase assay, varied by $>100$-fold with the different nitrogen sources, being high when $R$. leguminosarum biovar viceae is grown with glutamate or $\mathrm{KNO}_{3}$, and low with glutamine or $\mathrm{NH}_{4} \mathrm{Cl}$. This observation suggests that GSII activity is regulated at the transcriptional level. Moreover, it appears that GSII activity is not needed when $\mathrm{NH}_{4} \mathrm{Cl}$ is the nitrogen source and that it is instead needed to scavenge $\mathrm{NH}_{3}$ when glutamate or $\mathrm{KNO}_{3}$ are the nitrogen sources and the intracellular concentration of $\mathrm{NH}_{3}$ is low. On the other hand, it is not easy to understand how $\mathrm{NH}_{4} \mathrm{Cl}$ is utilized when it is the only nitrogen source, since GDH and GSII are undetectable, while GSI is almost completely adenylylated. It is possible that the in vivo activity of these enzymes is different from that extrapolated by the 


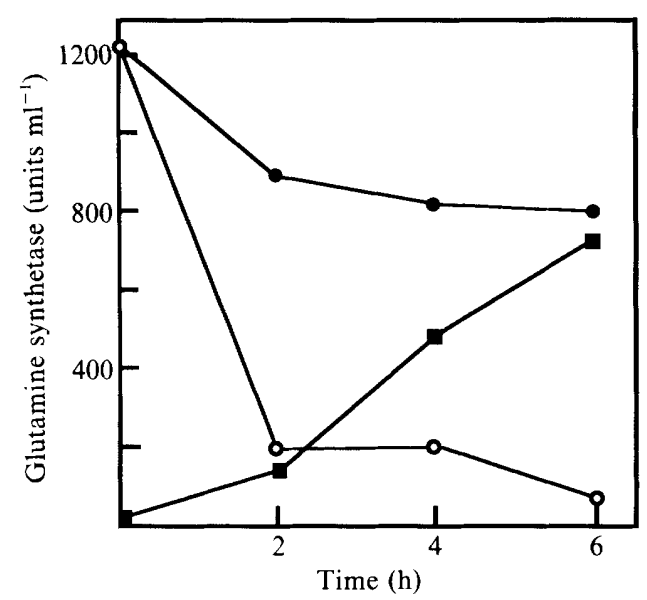

Fig. 5. Time course of GSII activity in crude extracts of $R$. leguminosarum grown in minimal medium, washed and resuspended in different nitrogen sources. $\mathrm{KNO}_{3} ; \mathrm{O}$, culture grown in glutamate and resuspended in $\mathrm{NH}_{4} \mathrm{Cl} ; \mathrm{O}$, culture grown in glutamate, resuspended for $1 \mathrm{~h}$ in chloramphenicol $\left(300 \mu \mathrm{g} \mathrm{ml}^{-1}\right)$ prior to the addition of $\mathrm{NH}_{4} \mathrm{Cl}$.

in vitro experiments, or that another enzyme(s) for $\mathrm{NH}_{3}$ utilization is present under these conditions.

\section{Metabolic shock}

We studied the kinetic changes of GSII levels when the nitrogen source in the medium was changed. When $R$. leguminosarum biovar viceae was grown in $\mathrm{NH}_{4} \mathrm{Cl}$, centrifuged while in exponential growth and resuspended in minimal medium containing $\mathrm{KNO}_{3}$, an increase in specific activity was observed (Fig. 5). When a culture growing in glutamine was centrifuged and resuspended in $\mathrm{KNO}_{3}$ analogous changes were observed (not reported in the figure).

If $R$. leguminosarum biovar viceae was grown with glutamate, centrifuged while in exponential growth and resuspended in $\mathrm{RMM}$ containing $\mathrm{NH}_{4} \mathrm{Cl}$, we observed (Fig. 5) a striking decrease in GSII transferase activity after $6 \mathrm{~h}$ incubation, from a value of 1210 to 65 , namely to $5 \%$ of the starting value. Since in these $6 \mathrm{~h}$ of incubation the turbidity of the culture increased by a factor of $16 \%$, if the decrease in GSII activity was due to repression then its value should have decreased to about $80 \%$. The high rate of disappearance suggests that a post-translational modification of GSII is taking place. This evidence is in agreement with results obtained with other Rhizobium and Bradyrhizobium spp.: Rhizobium 32Hl (Ludwig, 1980), B. japonicum and R. trifolii (Fuchs \& Keister, 1980), Rhizobium sp. ANU289 (Howitt \& Gresshoff, 1985) and R. phaseoli (Bravo \& Mora, 1980). When chloramphenicol was added prior to $\mathrm{NH}_{4} \mathrm{Cl}$ the activity decreased only to $60 \%$, thus suggesting that the presumed post-translational modification requires protein synthesis.

We thank $\mathrm{P}$. Gresshoff for bringing to our attention the possibility of acidification of the minimal medium when $\mathrm{NH}_{4} \mathrm{Cl}$ is the nitrogen source, $\mathrm{M}$. De Felice and G. Espin for revising the manuscript, P. Sparapani of Pierrel S.p.A. for fermenter growth of $R$. leguminosarum, A. Riccio for supplying plasmids and assisting in the slot-blot hybridization experiments, C. Migliaccio for technical assistance. This research work was supported by CNR, Italy, special grant IPRA Subproject 1 paper no. 2254. It was also partially supported by Pierrel S.p.A. (Caserta) and RASA-Realtur (Foggia).

\section{REFERENCES}

Bender, R. A., Janssen, K. A., Resnick, A. D., BlumenberG, M., FoOR, F. \& MAGasanik, B. (1977). Biochemical parameters of glutamine synthetase from Klebsiella aerogenes. Journal of Bacteriology 129, 1001-1009.

Bravo, A. \& Mora, J. (1988). Ammonium assimila- tion in Rhizobium phaseoli by the glutamine synthetase-glutamate synthase pathway. Journal of Bacteriology 170, 980-984.

Carlson, T. A. \& Chelm, B. K. (1986). Apparent eukaryotic origin of GSII from the bacterium $B$. japonicum. Nature, London 322, 568-570. 
Carlson, T. A., Guerinot, M. \& Chelm, B. K. (1985). Characterization of the gene encoding GSI $(g \ln A)$ from B. japonicum. Journal of Bacteriology 162, 698 703.

Carlson, T. A., Martin, G. B. \& Chelm, B. K. (1987). Differential transcription of the two glutamine synthetase genes of $B$. japonicum. Journal of Bacteriology 169, 5861-5865.

Colonna-Romano, S., Riccio, A., Guida, M., Defez, R., Lamberti, A., Iaccarino, M., Arnold, W., Priefer, U. \& PüHLER, A. (1987). Tight linkage of $g \ln A$ and a putative regulatory gene in $R$. leguminosarum. Nucleic Acid Research 15, 1951-1963.

DARROW, R. (1980). Role of glutamine synthetase in nitrogen fixation. In Glutamine Synthetase: Metabolism, Enzymology and Regulation, pp. 139-166. Edited by J. Mora \& R. Palacios. New York: Academic Press.

DARROw, R. A. \& K NOTTS, R. R. (1977). Two forms of glutamine synthetase in free-living root-nodule bacteria. Biochemical and Biophysical Research Communications 78, 554-559.

DixoN, R. (1984). Tandem promoters determine regulation of the $K$. pneumoniae glutamine synthetase ( $\ln A)$ gene. Nucleic Acids Research 12, 7811-7830.

ENGVALL, E. (1980). Enzyme immunoassay ELISA and EMIT. Methods in Enzymology 70, 419-439.

Ferguson, A. R. \& SimS, A. P. (1971). Inactivation in vivo of glutamine synthetase and NAD-specific glutamate dehydrogenase: its role in regulation of glutamine synthesis in yeast. Journal of General Microbiology 69, 423-427.

Filser, M. M. K., Moscatelli, C., Lamberti, A., Vincze, E., Guida, M., Salzano, G. \& Iaccarino, M. (1986). Characterization and cloning of two Rhizobium leguminosarum genes coding for glutamine synthetase activities. Journal of General Microbiology 132, 2561-2569.

Fuchs, R. L. \& Keister, D. L. (1980). Comparative properties of glutamine synthetases I and II in Rhizobium and Agrobacterium spp. Journal of Bacteriology 144, 641-648.

Gussin, G. N., Ronson, C. W. \& Ausubel, F. M. (1986). Regulation of nitrogen fixation genes. Annual Review of Genetics 20, 567-591.

hooykaas, P. J. J., KlapwiJk, P. M., Nuti, M. P., SCHILPEROORT, R. A. \& ROERSCH, A. (1977).
Transfer of the Agrobacterium tumefaciens TI plasmid to avirulent agrobacteria and to Rhizobium ex planta. Journal of General Microbiology 98, 477-484.

Howitr, S. M. \& GresshofF, P. M. (1985). Ammonia regulation of glutamine synthetase in Rhizobium sp. ANU289. Journal of General Microbiology 131, 14331440 .

LuDwIG, R. A. (1978). Control of ammonium assimilation in Rhizobium 32H1. Journal of Bacteriology 135 , 114-123.

LuDWIG, R. A. (1980). Physiological roles of glutamine synthetases I and II in ammonium assimilation in Rhizobium sp. 32H1. Journal of Bacteriology 141, 1209-1216.

Melton, D. A., Krieg, P. A., Rebagliati, M. R., Maniatis, T., ZinN, K. \& GreEN, M. R. (1984). Efficient in vitro synthesis of biologically active RNA and RNA hybridization probes from plasmids containing a bacteriophage SP6 promoter. Nucleic Acids Research 12, 7035-7056.

MoretT, E., Moreno, S. \& EsPIN, G. (1985). Impaired nitrogen fixation and glutamine synthesis in methionine sulfoximine sensitive (MSs) mutants of Rhizobium phaseoli. Molecular and General Genetics 200, 229-234.

Prusiner, S., Miller, R. E. \& Valentine, R. C. (1972). Adenosine 3'5'-cyclic monophosphate control of the enzymes of glutamine metabolism in $E$. coli. Proceedings of the National Academy of Sciences of the United States of America 69, 2922-2926.

Shapiro, B. M. \& StadtMan, E. R. (1970). The regulation of glutamine synthetase in microorganisms. Annual Review of Microbiology 24, 501-524.

Somer ville, E. \& KaHN, M. L. (1983). Cloning of the GSI gene from $R$. meliloti. Journal of Bacteriology 156, 168-176.

Stadtman, E. R. \& Ginsburg, A. (1974). The glutamine synthetase of $E$. coli: structure and control. In The Enzymes, vol. X, pp. 755-807. Edited by P. D. Boyer. New York: Academic Press.

Towbin, H., Staehelin, T. \& Gordon, J. (1979). Electrophoretic transfer of proteins from polyacrylamide gels to nitrocellulose sheets: procedure and some applications. Proceedings of the National Academy of Sciences of the United States of America 76, 4350-4354. 